\title{
APPLICATIONS OF BEHAVIOURAL ECONOMICS TO SAFEGUARD GEOHERITAGE $\&$ PROMOTE GEOTOURISM IN INDIA
}

\author{
Punyakrit Singh Ranawat \\ PGDM Student \\ Welingkar Institute of Management, Mumbai
}

\begin{abstract}
This paper is a thought, an attempt, to bring together two very different fields on the same page. Geoheritage \& Geotourism which concern themselves with the geological wealth of a country and how it can be converted into a booming opportunity for the tourism sector of a country and on the other hand the applications of Behavioural Economics and how the consumer can be motivated or nudged towards exploring the geological wealth of this country. The ideas that are presented in this paper stem from the fact that if multiple stakeholders such as Government, Businesses and Consumers, do their bit to promote geological sites of great importance in our country then not only can we conserve them for the future generations but we can also make sure that some economic contributions arise out of them. One would believe that the contribution has to be large enough in order for them to dip their toes in this field, but that really isn't the case here. With simple ideas and simple applications, we can increase the footfall of consumers in the National Geological Monuments (NGMs) of India and can churn a long cycle of economic contributions. Another aim of this paper is to highlight the modern methods of marketing communications which can be used to promote these sites, which the Government has already used in state tourism and enjoys success due to that model. The final aim is for the reader to understand that our Geoheritage not only remains less documented but also lacks a global recognition, which can be easily provided by converting the prominent sites into Geoparks, which then are recognizable as UNESCO Global Geoparks, a very successful initiative by UNESCO.
\end{abstract}

Keywords - Geoheritage, Geotourism, UNESCO Global Geoparks, Marketing Communications, Behavioural Economics, National Geological Monuments (NGMs)

\section{INTRODUCTION}

To bring to the general understanding of the readers of this paper let me define the two fields very briefly. Geoheritage are sites of natural importance which are packed with aesthetic features that are capable of alleviating the tourism properties surrounding the sites. Geoheritage sites are also important to the scientific communities around the world as they can help scientists and academicians understand the naturally occulting phenomenon of that area. I have talked about the National Geological Monuments (NGMs) both with recognized as well as showing potential in my past papers (Ranawat et al., 2019, Ranawat et al., 2020). On the other hand, behavioural economics is the branch that combines neuroscience, psychology and economic theory under one study. Richard Thaler and Cass Sunstein authored book "Nudge", talks fondly of the principles of economics with an added aspect of social sciences and psychology to it (Thaler et al., 2008). Similarly, Dan Ariely authored "Predictably Irrational" talks about the silent forces that can affect the way we take decisions (Ariely et al., 2008). While this is just a brief about the two very vast briefs, my aim in the paper is to bring the key research aspects from both the field and merge them in convincing arguments to supplement the thought that not only the Geoheritage sites in the country can be preserved for a sustainable future but they can also be promoted to increase Geotourism in our country. Also for supporting the views expressed in this paper and also letting the reader know the sites that I am talking about, I have mentioned examples (ideal sites) that the reader can look up and see for herself/ himself the geological sites that I am talking about and draw parallels between the sites and the headings under which they are mentioned.

\section{A CALL FOR 'CHOICE ARCHITECTS'}

In his book "Nudge", Dr. Richard Thaler, talks keenly about the influencing power of 'Choice Architects', they are people who have 'responsibility for organizing the context in which people make decisions'. These architects of choice have to make arbitrary decisions that induce subtle influences in our lives. The goal here is not to change the lifestyles of the people dramatically but instead in a well-defined and paced manner.

Now, with respect to the choice architects of the Geological wealth in our country, we have decision makers in the fields of Government, Non-Profit Organizations and Businesses. Starting with the Government, Geological Survey of India (GSI) looks at safeguarding and promoting the geological 


\section{International Journal of Engineering Applied Sciences and Technology, 2020 \\ Vol. 4, Issue 12, ISSN No. 2455-2143, Pages 415-422 \\ Published Online April 2020 in IJEAST (http://www.ijeast.com)}

wealth of our country and is an important stakeholder. State and National tourism bodies are also important and responsible departments of the government to promote and sustain Geological sites in our country. Non-Profit Organizations such as INTACH (Indian National Trust for Art and Cultural Heritage) are pioneers of geological conservation in our country. Lastly, businesses, be it local or national, operating in the fields of tourism and hospitality, can influence consumers in their own little ways for promoting tourism activities for Geoheritage sites. If we put all these stakeholders together then we can generate action plans with the likes of economic activity creation, sustainable development and community upliftment around the Geological sites of importance in our country.

Taking an example here, Lonar Lake in the Buldhana district of Maharashtra is a meteoric impact crater site with high concentration of saline constituents in the lake water (Tambekar, Pawar and Dudhane et al., 2010). But today this site isn't in the best of the conditions despite being one of the 190 confirmed crater impact sites in the world and one of the even much fewer meter impact lake formations in the world. The roads leading up to the lakes practically don't exist, the sign boards aren't maintained, the chlorides and salinity of the lake are deteriorating quickly, discharge of chemicals in the lake and human intervention are all spoiling the beautiful site. But imagine the role choice architects can play in this case, the GSI can fix the sign boards and roads in the area, put people from nearby villages on duty for protection of the lake at a very minimum wage and kickstart an economic cycle. The non-profit organizations can generate awareness drives in communities about these sites and build the story for this site and other such examples in local communities and influence them to protect the lake. Businesses in the fields of hospitality and tourism either from the state or around the Geoheritage site can recommend a visit to this site and promote it in a fruitful manner. In this manner all the stakeholders can get occupied in small activities that together can help achieve a much larger purpose.

\section{Suggested NGMs:}

1. Zawar Metallurgy \& Mining Site, Udaipur District, Rajasthan

2. Ramgarh Crater Site, Kota, Rajasthan

3. Balancing Rock, Jabalpur, Madhya Pradesh

4. Krishna's Butter Cup, Mahabalipuram, Tamil Nadu

\section{INTRODUCING A NUDGE}

Now that we have the choice architects in place, we can move towards the creation of libertarian paternalism and translate it into a nudge. Nudge is any factor that can significantly alter the behaviour of humans. There are many ways to nudge people, one of the quickest ways that you can possibly identify is an incentive. Introduce an incentive and the likelihood of someone completing the task in hand increases. But we cannot replicate that model here, because the Government would simply have to 'invest' a lot of money in the preservation and promotion of these sites. So, while we can ignore the likelihood of incentives to get things in order with respect to the Geoheritage wealth in our country, people can be nudged by means of 'competition'. The Government of India runs a fabulous campaign called the 'Swachh Bharat Abhiyan' or 'Clean India Mission' which focuses on universal sanitation coverage. The mission is further supported by 'Swachh Survekshan' which is a report that captures the sanitation levels of 4237 cities (Ministry of Housing and Urban Affairs et al., 2019), while encouraging citizen participation in sanitation and cleanliness drives around the country.

Suggestion: The Government can replicate the same model for citizen awareness and participation. This doesn't require large hoardings or big rallies, small mentions from the government officials in their respective zones can activate a similar campaign around these sites. Building it further, a similar report can be published annually or semi-annually that surveys the conditions of Geoheritage sites around the country. To add the dimension of scalability here, the reader must note that as of today, there are 34 recognized National Geological Monuments (NGMs) in India, so the survey doesn't have to utilize as many resources as the Swachh Survekshan report each year does. Addition of competition is another small nudge which the official bodies like Geological Survey of India (GSI) can implement in this survey to invoke community participation in order to preserve the geological wealth that surrounds them and then the places that are maintained in the best possible manner can be given different rewards and recognitions. Over time this simple nudge will be enough for tourists or travellers to seek out these destinations as well, as they will see the involvement of communities in the active monitoring and preservation of these sites and the potential for the sites in our country to get converted into UNESCO Global Geoparks will increase exponentially. Once the site has been identified by the government for development into a UNESCO Global Geopark then the tourism activities surrounding that site can be expanded and the local businesses be befitted as well, also not forgetting the fact that a UNESCO recognition will put our geological wealth in the spotlight for international scientific, academic and traveller communities.

\section{Suggested NGMs:}

1. Akka Mahadevi Caves, Telangana

2. Lonar Lake, Maharashtra

3. Pawar Pinnacle, Raigad, Maharashtra

4. Zanskar Valley, Kargil District, Jammu \& Kashmir

5. Floating Rock, Meghalaya 


\section{International Journal of Engineering Applied Sciences and Technology, 2020 \\ Vol. 4, Issue 12, ISSN No. 2455-2143, Pages 415-422 \\ Published Online April 2020 in IJEAST (http://www.ijeast.com)}

\section{PUTTING A VALUE TO THESE SITES}

One of the important aspects for behavioural economists is to understand the intrinsic value of something and assign that value to the product or service in hand, only then can they design nudges for people to react to. As humans we assign value to each and everything in our mind, be it tangible or intangible, we assign some kind of value to our possessions. In this similar manner, we need to assign both a tangible and intangible value to the Geoheritage sites around the country. The most tangible ways for people to realize this would be by putting a small price tag on these sites, saying that it would take ₹50/- (hypothetical example) for a consumer to visit this place. Now, this monetary aspect will add a frame of reference quickly in the minds of the consumers. They will start comparing it with other public places or architectural marvels in the country or even other UNESCO World Heritage Sites (which already people confuse these geological sites with). Let me be clear, confusion creation isn't the goal here, it is for consumers to have a 'frame of reference' and comparison of these sites with something that they might already be familiar with. Moving on towards the intangible value creation, this is trickier but if successfully implemented then it will see more impact than the tangible aspect. Here the goal is to influence people's perception and attitude towards NGMs. Citizens need to pay heed to the fact that these sites aren't just naturally occurring architectures, these sites can critically advance the knowledge about natural phenomenon such as groundwater supply fluctuations, mineral and energy supply levels, environmental changes, soil processes, evolution of life and other hazards. These sites have huge potential for classroom visits, economic activity creation around the area, support for local communities (which they already tend to draw from these sites), enhancing knowledge in the public domain and other such potentials that give rise to intangible benefits in the society. Once understood and internalized then people will automatically have a different lens towards these sites while visiting them. For example: they might stop spreading litter around these sites, stop drawing graffiti on them, carving their names in stone etc., which is why the intangible benefits are important to understand and convey.

\section{Suggested NGMs:}

1. Gandikota, Andhra Pradesh

2. Belum Caves, Andhra Pradesh

3. Gongoni, West Bengal

4. Natural Coral Bridge, Andamans

5. Yana Rocks, Karnataka

\section{SUSTAINABLE PRESERVATION GOALS (SPGs) FOR GEOHERITAGE SITES}

Preservation is important to propel the historic value of geological monuments in our country. My proposal here is on the similar lines as the well laid down Sustainable Development Goals (SDGs) by the United Nations. Geoconservation is the shift of focus from the conservation of only living creatures to non-living things as well. These include geological features, landforms and soils (Sharples et al., 2002). These non-living parts of nature play a vital role in healthy promotion of biodiversity. According to a paper titled, "Geology and Sustainable Development Goals" (Joel Gill et al., 2016), 11 of the 17 agreed SDGs are influenced by key aspects of geology. The aspects that the paper considered were Geoheritage, geohazards, geo-engineering, agro-geology, climate change, energy, hydrogeology, geo-education, geological capacity building and a miscellaneous category. This way the paper aims to bring together the significant impact that geology students, educators, industry professionals, researchers and policymakers can have on the UN SDGs 2030. My proposal here is to have separate emphasis on Geo-conservation before development. In most cases, it isn't easy to develop these sites due to multiple reasons or lack of resources, while that is the case, preservation is the least of the asks in the list. If we cannot preserve what we already have then how can we develop what we won't in the future. Elaborating this thought further, Sustainable Preservation Goals (SPGs) for geological sites are important and following would be some of the starting points for preservation:

1. Sanitation of geological sites and areas around them, reducing the footprint of the communities around them, in a positive manner

2. Understand Disaster Risk Reduction and prepping these sites in advance if they are susceptible to landslides, earthquakes, tsunamis, etc.

3. Energy supply management of these sites by maintaining the safe level of mineral extraction from these sites

4. Biodiversity management and Environment conservation by understanding the impact of various kinds of pollutions near these sites

5. Maintenance of basic infrastructure around these sites, which includes signage boards, roads, etc.

Now that we have a starting point in our minds we can always develop further on these sites, as and when the necessary allocations from the government are made to these sites, but until that happens, it is of paramount importance that we preserve/ conserve these sites before going ahead with their development into anything.

\section{Suggested NGMs:}

1. Natural Gateway Near Lachung La, Himachal Pradesh 


\section{International Journal of Engineering Applied Sciences and Technology, 2020 \\ Vol. 4, Issue 12, ISSN No. 2455-2143, Pages 415-422 \\ Published Online April 2020 in IJEAST (http://www.ijeast.com)}

\section{Marvel of Weathering \& Erosion, Leh, Himachal Pradesh \\ 3. Bedded Barytes, Mangampeta, Andhra Pradesh}

\section{INTRODUCING AN 'ENTRY TICKET'}

The first thing that a tourist does is purchase an entry ticket, whenever they visit an architectural marvel built by some prominent figure in history, which has an added element of storytelling around it (courtesy of the multiple tourist guides). A simple ₹ $10 /-$ ticket has more to do with a 'value tag' rather than just a revenue opportunity for the tourism department of the state. It tells the people that what they are about to witness is important. Of course, the price tag can always be adjusted to meet the needs of administration and the people who are actually looking after the site, or mainly because the demand to see the marvel might be far overwhelming to let go of an additional revenue. But the point that I am trying to make here is that whenever you put that monetary value to these sites, by introducing a ticket, a tour guide who can talk about the qualities of the place, an additional car to tour the vicinity of the site, then the value of the place increases a lot and suddenly it is taken far more seriously than before. The goal for public policy makers in conjunction with the tourism departments of the country should be the same, to increase the fair value of our Geoheritage wealth and at the same time not let the price tag be a burden for the average consumer, but instead be a motivating factor for them to go visit some of the best geological sites in our country and spend some quality time with the wonders of our land.

\section{Suggested NGMs:}

1. Natural Arch, Tirumala Hills, Andhra Pradesh

2. Kolodyne Caste, Mizoram

\section{THE NEURONS OF ECONOMICS, MARKETING AND TOURISM}

Let me introduce 3 terms here that you might or might not be familiar with: Neuroeconomics, Neuromarketing and Neurotourism. A relatively newer branch of science (Neuroeconomics) that looks inside our brains to figure out how we make decisions. Pschologists in Stanford have studied the effects of feelings and emotions whem consumers are considering to make microlending decisions (Kuntson et al., 2015 and Genevsky et al., 2015), in such a project they have analysed the data from neuroimaging scans and tried to understand what are the key drivers of a certain kind of decision, what emotions will influence the way we make daily decisions. Neuromarketing, which is often termed as 'Consumer Neuroscience', studies the brain and tries to influence consumer decision making in the process (Harrell et al., 2019). Moreover, this branch aims to look at the physiological and neural signals to gain insights into the minds of the consumer(s). Aim here is to study the preferences and motivations to choose some product or service over another. Lastly, not only is the science of our brain an interesting one and being applied in multiple directions (two of them mentioned above), but it is already being applied to the tourism sector as well (termed as Neuro-tourism). The various motivations for travelling, the way they adapt to a certain kind of holiday agenda (honeymoons, leisure, business travel, others), the changes in the behaviour of people during holidays and travels, determining what consists of a 'good vacation', perceptions, attitudes, etc., are some of the many things that neuroscience and tourism management aim to combine to draw parallel and build models to support economic activities arising in the tourism field. Now, I understand that to the reader, I have thrown three different branches of study here, but I am not going to tell you further about all of them, because they are beyond the scope of this paper, but what I am going to tell you is that these branches are all related and ultimately for Geotourism to be successful not only in India but in the world, we need to dedicate some resources to the study of consumer decision making with regards to geological sites and why I certain customer would or wouldn't visit these sites. This can lead to the next logical step of neuromarketing and campaigns can be designed more appropriately for the customers (in order to better target advertisements at them).

\section{Suggested NGMs:}

1. Siwalik Fossil Park, Saketi, Himachal Pradesh

2. Akal Fossil Wood Park, Jaisalmer, Rajasthan

\section{POLICIES THAT ENABLE A 'BANDWAGON EFFECT'}

By definition 'Bandwagon Effect' is the "phenomenon whereby the rate if uptake of beliefs, ideas, fads and trends increases at a greater pace when they have already been adopted by others", or simply it is a psychological phenomenon wherein people tend to do something because a lot of other people are doing it. Now for policy makers who have the power of influencing crowds through nudges, and the marketeers who have the power to tell unique propositions about these sites in a creative manner it becomes really important that the aim of creating a bandwagon effect here is achieved, which will be more fruitful while promoting NGMs. Not only can this attract a significant hype around these sites, but can also offer a higher possibility of people visiting these sites. Hence, it is urgent for policy makers to consider this perspective while drafting recommendation(s) in regards with these sites.

\section{Suggested NGMs:}

1. Lalbagh Botanical Gardens, Bangalore 


\section{International Journal of Engineering Applied Sciences and Technology, 2020 \\ Vol. 4, Issue 12, ISSN No. 2455-2143, Pages 415-422 \\ Published Online April 2020 in IJEAST (http://www.ijeast.com)}

\section{Columnar Basalt, Coconut Island, Karnataka}

\section{SOCIAL NORMS APPROACH TO CURB UNDESIRABLE BEHAVIOUR}

A very important battle that the National Geological Monuments (NGMs) and the other geological wealth in our country constantly face is undesirable behaviour towards these sites, which includes littering near these sites, mining activities, defecation, discharge of industrial chemicals and waste, to list a few. Now these are important to be curbed if the goal is to at least start preserving these sites first (as suggested in Sustainable Preservation Goals earlier), following which we can move ahead and develop these sites. Now the 'Social Norms Theory' was initially used in the year 1986 by Perkins and Berkowitz to address the student alcohol usage patterns. This theory has mainly been used in the public-health domain, but the idea is quite straightforward here: as a person, should I engage in certain kinds of behaviour or not (Ajzen et al., 1991), what will my peers think about me if I engage in that behaviour, what are the established societal norms or views with regards to my actions? If we can draw insights from this approach and set certain 'social norms' or 'collective views' with regards to certain actions then it will be far easier for us to convince people of their undesirable behaviour than taking any other approach. While we see that a lot of damage is done to geological sites around the country and the world as well, a collective lens can be dawned upon by people to shun the undesirable behaviour around these sites. Signage can show more stringent actions against the perpetrators, visual images to capture the attention of visitors can be used, other communication can be made to ensure that visitors understand the importance of the place they are visiting and the sophistication that they need to maintain around it. At the same time it is the task of the government as well to ensure that proper trash chutes are placed on these sites, so that the incentive to dump waste openly is minimized, also for the local communities to take actions when they see misuse of these places (especially in the case of illegal mining activities and chemical waste treatment around these sites). By understanding the social norms with regards to these places and the way people will react to certain good or bad actions, processes can be made simpler here.

\section{Suggested NGMs:}

1. National Fossil Wood park, Villupuram

2. National Fossil Wood park, Sathanur Perambalur

3. Bedded Barytes, Andhra Pradesh

\section{SIGNAGE BOARDS WITH VISUAL FEEDBACK}

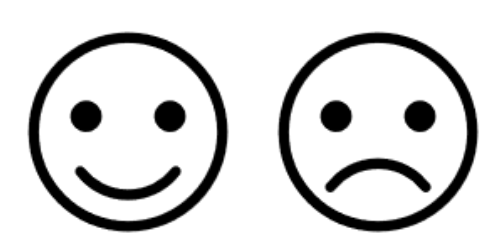

Look at the above figure, and you can understand that visual feedback for things can easily be provided to anyone and anywhere using just the two faces alone: one happy and one sad. For visitors in these geological sites, signage boards can easily feature such visual aids with two columns displaying Do's and Don'ts of the visit. Not only does the visual attract instant attention, but customers are likely to read the signage boards and understand the various norms of social conduct. This simple trick can be used not only in the geological sites but in other architectural places as well to curb undesirable activities like spitting.

\section{Suggested NGMs:}

1. Lalbagh Botanical Gardens, Bangalore

2. Columnar Basalt, Coconut Island, Karnataka

\section{PRIMING FOLKS}

Our brains do work in mysterious ways and one way to capture our attention is through subtle influences and these influences in turn guide/ direct our behaviour and we get 'Primed' to do something (or not). In the context of social settings, it will come as a revelation to you, if I told you that the next time you wish to holiday, you should consider the city of 'Udaipur' as your destination, and if I also added the fact that it is often termed as, 'The City of Lakes' or 'The Venice of the East', amongst many other names and that every corner of the city which was founded in the year 1553 by Maharana Udai Singh, has a story to tell. Having mentioned all these facts to you, and considering that you have internalized these facts, the next time you do consider to make a holiday somewhere in the country, the city of Udaipur will surely come to your mind at least once, and this is an example of 'Priming' people. This small nudge can have a significant impact. Kurt Lewin, who is often recognized as the "founder of social psychology" identified something called "channel factors' in his research (1951), which are small influences that could either inhibit or facilitate certain behaviours in us (Thaler et al., 2008). A very famous case surrounding the usage of channel factors was perhaps displayed on the campus of Yale University (Leventhal, Singer and Jones et al., 1965) in the year 1965, where subjects were communicated about the various risks of tetanus and the value of vaccination to prevent it, this simple communication was enough to change the attitudes and beliefs of people (as it was later concluded by follow-up surveys). In a similar manner if we communicate 


\section{International Journal of Engineering Applied Sciences and Technology, 2020 \\ Vol. 4, Issue 12, ISSN No. 2455-2143, Pages 415-422 \\ Published Online April 2020 in IJEAST (http://www.ijeast.com)}

the importance, beauty and other features of the NGMs in our country to the people, either by means of newspaper, radio or social media, then we can expect a higher percentage of people who will consider visiting these sites over their next holiday trip or a local adventure. Another way to spread the communication would be by surveys, which probe a simple question, 'Have you visited any National Geological Monuments in India?' or, 'Are you planning to visit a National Geological Monument as part of your next holiday itinerary?', such questions will spark interest in potential customers, they will research about these sites, the destinations that they are located in, plan other things as part of their itinerary to do while they are holidaying, and that is the final goal here, for the customers to include these sites in their holiday plans. Alone these sites wouldn't be enough to spark interest in a regular consumer (because these sites are often of prime interest to the academic and scientific community), but coupled with the beautiful cities that these sites are often a part of, the places can easily be included in your holiday itinerary.

\section{Suggested NGMs:}

1. Zawar Metallurgy \& Mining Site, Udaipur District, Rajasthan

2. Ramgarh Crater Site, Kota, Rajasthan

\section{SOCIAL MEDIA MARKETING}

In today's age, communication surrounding geological sites sees less significance, and while I can understand that till the time we don't see some great success arising from tourism activities and other economic activities that are because of these sites, the government wouldn't want to put the taxpayers money into traditional forms of advertising be it via newspapers, magazines, television among other forms of media. But it will be much cheaper, impactful and immediate if the government and other authorities diverted their focus on ensuring that dedicated social media pages for these sites are put up across social media platforms that have millions of monthly active users. A simple social media handle, with frequent news, posts, articles, pictures, videos, surrounding these sites will help achieve three pronged objectives which are:

1. Disseminate 'Information' in the public domain about these sites

2. Add a layer of 'Authenticity' around these sites

3. And help generate 'Buzz' around these sites of importance

Having met these 3 objects and hopefully generated enough 'likes/ followers/ tweets' around these sites, a more investment friendly plan can then be set into motion. This plan will focus on paid advertisements and targeted advertisements which considering the vast amount of data today that social media users generate each day, would be a rather successful attempt at promotion of these sites, rather than just individuals from the government mentioning these sites in one odd speech or raising concerns in one odd meeting regarding them. This thought can further be expanded by creation of 'Online Communities' or 'Social Media Forums' wherein the scientists, academicians, policy makers, etc., key stakeholders can then interact with the citizens of the country and spread more information about the geological wealth of our country. I could go on listing the future applications that can arise from social media marketing and social media handles, but the most important fact that I stated further which requires another mention is that: Costs will be minimal when using these forums, which is an added incentive for stakeholders (to use these platforms for marketing and informative purposes).

\section{Suggested NGMs:}

1. Lalbagh Botanical Gardens, Bangalore

2. Columnar Basalt, Coconut Island, Karnataka

3. Natural Arch, Andhra Pradesh

4. Natural Coral Bridge, Andamans

\section{GENERATING FEEDBACK FROM THE SCIENTIFIC COMMUNITY}

So far, I have discussed the economic advantages that can arise from these sites, as well as the different nudges that can be introduced to bring these sites in the limelight. Nevertheless, I also need to point out the power and effect of updates research that can be a courtesy of the scientific/ academic community in the field of history, geology and environment. While customers, communities, citizens can do their bit to preserve these sites and promote them, what the scientists need to do is revisit these NGMs on a frequent basis to study the effects of the concerns raised earlier in the paper (such as mining activities, human activities, industrial activities, etc). An updates research will help bring to light the current state of these sites and then that data will become crucial in adjusting the steps that are being taken by the policy makers. This feedback loop can help establish ground realities concerning various sites and whether economic activities are helping the local communities, local businesses, the state or not and also the changes in the environmental footprint (if they are being realised). This feedback loop will set the next priorities and agendas for policy makers in place and also help in the identification of higher potential geological sites which can then be easily converted into UNESCO Global Geoparks. This tag from UNESCO would be of extreme importance to our country, not only because of an international recognition, but it will help double the efforts that are surrounded in making these sites constantly better for public usage.

\section{Suggested NGMs:}




\section{International Journal of Engineering Applied Sciences and Technology, 2020 Vol. 4, Issue 12, ISSN No. 2455-2143, Pages 415-422 \\ Published Online April 2020 in IJEAST (http://www.ijeast.com)}

1. Ramgarh Crater Impact Site, Kota, Rajasthan

2. Zawar Mines, Udaipur District, Rajasthan

\section{CONCLUSION(s)}

1. It is possible for Geologists, Policy Makers, Government(s) to look at the branch of behavioural economics and draw insights about the consumers in any field, and with specific reference to this paper it is possible for them to connect the dots between Geotourism enhancement, Geoheritage Preservations (Sustainable Preservation Goals) and Behavioural Economics.

2. The role of Policy Makers and the Governments(s) is not extended to becoming effective 'Choice Architects', who can influence the way we think in subtle mannerisms of policy advocacy.

3. Nudges become crucial in changing the way our society currently looks at the geological wealth in our nation, I am not saying that they hate it or are deliberately spoiling it, it's just unknowingly a lot of us get involved in those acts and the 'collective ignorance' now needs to be shunned away.

4. A tangible as well as intangible value that we assign to these sites is very important in order for people to be able to compare them or have a frame of reference in their minds when they are visiting these sites.

5. Sustainable Preservations Goals (SPGs) need to be developed separately with different sub-tasks to be done in order to first preserve what we have and then develop what we have into something better.

6. Policy Makers, Government(s), Non-Profit Organizations (like INTACH) or just about anyone who is trying to make a difference in this field will not only benefit from the principles of behavioural economics but they will also benefit from the principles of Neuroeconomics, Neuromarketing and Neurotourism (as mentioned earlier in the paper)

7. Establishing social norms towards undesirable behaviour is important and so is giving visual feedback to the customers.

8. Priming the customers with information that can be made available in the public domain as well as asking the right questions to customers is important in order to nudge people towards changing their views about these sites as well as making them visit these sites.

9. Social Media Marketing is the most affordable form of advertising and marketing communications that the government can adopt to in order to better promote these websites without having to allocate a lot of money to these efforts and still see positive results.

10. Lastly, it is important to involve the scientific community to generate up-to-date research about the condition of these sites and take recommended courses of action from them to improve the sites further.

\section{ACKNOWLEDGEMENTS}

Significant credit goes to Dr. Pushpendra Singh Ranawat, who has always guided my research by adding precise thoughts and views to it. I am also grateful to my parents who have always guided me and taught me ways to conquer any kind of situation.

\section{REFERENCES}

1. Ranawat, P. (2020). Recognized Geoheritage \& Geotourism Sites in India. Research Paper: International Journal of Engineering Applied Sciences and Technology, Vol 4., Issue 11, ISSN No. 2455-2143, (pp. 224-231)

2. Ranawat, P. (2019). Potential Geoheritage \& Geotourism Sites in India. Research Paper: International Journal of Scientific and Research Publications, Volume 9, Issue 6, June 2019, ISSN 2250-3153, (pp. 91-96)

3. Ranawat, Dr. P.S. (2016). Geoheritage of Udaipur Region. Udaipur, Rajasthan: Kumbha Exclusives (pp. 1-2)

4. Ranawat, Dr. P.S. (2016). Monograph on National Geological Monuments and Potential Geoheritage Sites of Rajasthan. Udaipur, Rajasthan: Kumbha Exclusives.

5. INTACH (2016). A Monograph on National Geological Monuments of India. Lodhi Estate, New Delhi: Indian National Trust for Art and Cultural Heritage

6. Kotler, P., Keller, K., Koshy, A. and Jha, M. (2013). Marketing Management: A South Asian Perspective (14E). Noida, Uttar Pradesh: Dorling Kindersey (India) Pvt. Ltd. (pp 14-16, 29-32, 111-113)

7. Department of Mining and Geology, Thiruvananthapuram (November, 2016). District Survey Report of Minor Minerals (Except River Sand)-Malappuram District, (pp. 13)

8. Thaler, R. and Sunstein, C. (2008, 2009). Nudge: Improving Decisions about Health, Wealth and Happiness. England: Penguin Books Ltd. (pp. 19-21, 39, 46-47, 79-85, 89-91, 193) 


\section{International Journal of Engineering Applied Sciences and Technology, 2020 \\ Vol. 4, Issue 12, ISSN No. 2455-2143, Pages 415-422 \\ Published Online April 2020 in IJEAST (http://www.ijeast.com)}

9. Thaler, R. (2015). Misbehaving: The Making of Behavioral Economics. (pp. 36-39, 115-117)

10. Ariely, D. (2008). Predictably Irrational: The Hidden Forces That Shape Our Decisions. United States of America: HarperCollins. (pp. 23-26, 67-71, 89-92)

11. Tambekar, D.H., Pawar, A.L. and Dudhane, M.N., (2010). Lonar Lake Water: Past and Present.

12. Loewenstein, G., and Sutherland, R., (2014). The Behavioural Economics Guide 2014. (pp. 1-4, 5156).

13. Bertrand, M., Mullainathan, S., and Shafir, E. Behavioural Economics and Marketing in Aid of Decision making among the Poor. (pp. 6-11)

14. Jashi, C. (2013). Research Paper: Significance of Social Media Marketing in Tourism. (pp. 1-2)

15. Giudici, E., Dettori, A., and Caboni, F. (2017). Research paper: University of Verona. Neurotourism: Futuristic Perspective or today's reality? (pp. 335, 339, 343)

16. Camerer, C., Cohen, J., Fehr, E., Glimcher, P., and Laibson, D. Handbook of Experimental Economics. Neuroeconomics. (pp. 2, 5, 36)

17. Berkowitz, A.D. (2004). The Social Norms Approach: Theory, Research and Annotated Bibliography. (pp. 5, 14)

18. Sharples, C. (2002). Concepts and Principles of Geoconservation. Published electronically on the Tasmanian Parks \& Wildlife Service Website. (pp. 16-21)

19. Burlando, M., Firpo, M., Queirolo, C., Rovere, A., and Vacchi, M. (2010). Research Paper: SpringerVerlag 2011. From Geoheritage to Sustainable Development: Strategies and Perspectives in the Beigua Geopark (Italy).

20. Gill, J.C. (2016). Research Paper: British Geological Survey. Geology and the Sustainable Development Goals. (pp. 1-4)

21. Cai, Y., Han, J., and Chu, H. (2019). Research Paper: Springer. Geoheritage and Sustainable Develpoment in Yimengshan Geopark. (pp. 2-3)

22. Parker, C.B. (2015). A Smile Boosts the chances of getting a microloan, says Stanford psychologists. Access: https://news.stanford.edu/2015/08/20/microloans-psychology-082015/

23. Harrell, E. (2019). Neuromarketing: What you need to know. Access: https://hbr.org/2019/01/neuromarketing-what-youneed-to-know

24. Geodiversity, Geoheritage \& Geoconservation: the ProGEO simple guide (2017). Access:
http://www.progeo.ngo/downloads/ProGEO_leaflet_ EN_2017.pdf

25. Social Norms Theory. Access: http://sphweb.bumc.bu.edu/otlt/MPH-

Modules/SB/BehavioralChangeTheories/BehavioralC hangeTheories7.html

26. Land, V.R. Social Media and Tourism Marketing: A Match Made in Heaven. Access: https://uhurunetwork.com/social-media-and-tourismmarketing/

27. Earth Impact Database: Access: http://www.passc.net/EarthImpactDatabase/New\%20 website_05-2018/Index.html

28. Swachh Survekshan 2019: Ministry of Housing and Urban Affairs: Government of India: Access: swachhsurvekshan2020.org/Images/SS2019\%20Repo rt.pdf

29. Sustainable Development Goals: Access: https://sustainabledevelopment.un.org 